\title{
FAKTOR YANG MEMPENGARUHI KETEPATAN ANGGARAN SEKTOR PUBLIK
}

\section{Fajar Saputro ${ }^{1}$, Bambang Setyobudi Irianto $^{2}$, dan Eliada Herwiyanti ${ }^{3}$}

1Pemerintah Daerah Kabupaten Cilacap

2Jurusan Akuntansi, Fakultas Ekonomi dan Bisnis, Universitas Jenderal Soedirman, Jl. HR. Boenyamin No. 708, Purwokerto 53122, Jawa Tengah, Indonesia

3Jurusan Akuntansi, Fakultas Ekonomi dan Bisnis, Universitas Jenderal Soedirman, Jl. HR. Boenyamin No. 708, Purwokerto 53122, Jawa Tengah, Indonesia

*Email corresponding author: bb.setyobudi@gmail.com

\begin{abstract}
Abstrak
Pelaksanaan anggaran dari pemerintah daerah di Indonesia selalu menjadi perhatian dari pemangku kepentingan, fenomena akurasi anggaran adalah salah satu dari perhatian tersebut. Pelaksanaan anggaran daerah di Indonesia selalu menghasilkan SILPA, yaitu kelebihan anggaran dengan realisasi, fakta-fakta menunjukkan ketidakakuratan pelaksanaan APBD secara empiris. Penelitian ini dilakukan dalam rangka menunjukkan peran tekanan eksternal, ketidakpastian lingkungan, komitmen organisasi dan kualitas anggaran dari akurasi anggaran.

Metode penelitian menggunakan metode kuantitatif dengan pendekatan explanatory, pengumpulan data dilakukan dengan menggunakan kuesioner dan didistribusikan ke eselon 4 pejabat yang terlibat dalam perencanaan, mengimplementasikannya, pemantauan, pengendalian dan evaluasi anggaran di Cilacap pemerintah daerah, menggunakan metode purposive sampling untuk mendapatkan sampel penelitian dan menggunakan Warp PLS 0,4 sebagai statistik alat uji. Hasil penelitian menunjukkan bahwa tekanan eksternal dan ketidakpastian lingkungan berpengaruh signifikan negatif pada akurasi anggaran dan komitmen dari kualitas organisasi dan anggaran memiliki pengaruh yang signifikan positif terhadap akurasi anggaran.

Penelitian ini memberikan kontribusi kepada pemerintah daerah untuk meningkatkan akurasi anggaran dengan mengoptimalkan komitmen organisasi dan kualitas anggaran, dan juga meningkatkan kesadaran dalam terang ketidakpastian eksternal dan lingkungan dengan bijak. Kontribusi lain adalah penelitian ini memberikan manfaat akademis untuk pengembangan teori akuntansi sektor publik.

Kata kunci: Tekanan Eksternal, ketidakpastian lingkungan, komitmen organisasi, kualitas anggaran, akurasi anggaran, SILPA.
\end{abstract}




\begin{abstract}
Budgets implementation of local goverment in Indonesia has always been a concern of stakeholders, the budget accuration phenomenon is one of them. Local budgets implementation in Indonesia always produce SILPA, namely the excess of budget with the realization, the facts indicate inaccuracies of local budget implementation. This research was conducted in order to empirically demonstrate the role of external pressures, environmental uncertainty, organizational commitment and budget quality of budget accuracy.

The research method uses quantitative methods with explanatory approach, data collection conducted by using questionaire and distributed to echelon 4 officials who involved in planning, implementating, monitoring, controling and evaluating of budget in Cilacap local goverment, use purposive sampling methode to get research sample and using Warp PLS 0.4 as a test tool statistics. The results showed that external pressure and environmental uncertainty has a negative significant effect on budget accuracy and commitment of the organization and budget quality has a positive significant effect on budget accuracy.

This study contributes to local governments to improve budget accuracy by optimizing the organizational commitment and budget quality, and also raise awareness in light of external and environmental uncertainty wisely. Another contribution is that this study provides academic benefits for the development of theory in public sector accounting.

Keywords: External pressure, environmental uncertainty, organizational commitment, budget quality, budget accuracy, SILPA.
\end{abstract}


Faktor Yang Mempengaruhi Ketepatan Anggaran...

\section{PENDAHULUAN}

Era otonomi daerah dimulai dengan dikeluarkannya Undang-Undang Nomor 32 Tahun 2004 tentang Pemerintah Daerah dan Undang-Undang Nomor 33 Tahun 2004 tentang Perimbangan Keuangan antara Pemerintah Pusat dan Daerah yang memberikan kekuatan baru pada Pemerintah Daerah. Menurut PP Nomor 58 Tahun 2005 tentang Pengelolaan Keuangan Daerah pasal 1 ayat 6 diamanatkan bahwa pengelolaan keuangan daerah adalah keseluruhan kegiatan yang meliputi perencanaan, pelaksanaan, penatausahaan, pelaporan, pertanggungjawaban, dan pengawasan keuangan daerah.

Sebagaimana disebutkan dalam Pasal 1 ayat 5 Undang-Undang Nomor 32 Tahun 2004, telah diamanatkan bahwa pengelolaan anggaran secara transparan dan akuntabel serta berdasarkan prinsip value for money. Menurut Mardiasmo (2002), diterapkannya prinsip value for money mengindikasikan berhasilnya pelaksanaan otonomi daerah melalui terjadinya peningkatan pelayanan dan kesejahteraan masyarakat yang semakin baik, kehidupan demokrasi yang semakin maju, terciptanya keadilan, pemerataan, serta adanya hubungan yang serasi antara pusat dan daerah serta antar daerah.

Anggaran tidak hanya sebagai alat perencanaan keuangan dalam sistem pengendalian manajemen tetapi juga sebagai alat pengendalian, kebijakan fiskal, koordinasi dan komunikasi, alat politik, penilaian kinerja, motivasi dan sebagai alat untuk menciptakan barang publik (Mardiasmo, 2009). Tidak berfungsinya anggaran secara ideal memiliki efek terhadap kegiatan pembangunan. Fakta penyerapan anggaran yang rendah, dan melampaui target serta tidak tepat waktu sehingga mengakibatkan pencapaian target dan sasaran dari anggaran yang telah di alokasikan untuk pembangunan menjadi tidak tepat.

Fenomena ketepatan pelaksanaan anggaran dengan indikator SILPA ditemukan di Kabupaten Cilacap dalam kurun waktu lima tahun anggaran yaitu tahun 2010 sampai dengan tahun 2014. Selisih antara target dan realisasi pendapatan dan belanja yang menunjukkan kinerja pelaksanaan anggaran terjadi pada Kabupaten Cilacap yang disajikan dalam tabel 1.

Berdasarkan keterangan yang diperoleh dari hasil wawancara dengan Kepala Bidang Akuntansi dan Kepala Bidang Pendaftaran dan Pendataan Pendapatan pada Dinas Pengelola Pendapatan, Keuangan dan Aset Daerah (DPPKAD) Kabupaten Cilacap, dinyatakan bahwa SILPA berasal dari selisih antara anggaran pendapatan dan anggaran belanja serta anggaran pengeluaran pembiayaan dengan realisasinya. Terjadinya selisih anggaran belanja dengan realisasinya bersumber dari upaya penghematan belanja dan adanya belanja yang tidak dapat dieksekusi sehingga anggaran tidak dapat diserap 100\%. Sedangkan selisih anggaran pendapatan dengan realisasinya bersumber dari pelampauan target anggaran yang telah ditetapkan. 
Tabel 1. Ketepatan Anggaran Pemerintah Kabupaten Cilacap

\begin{tabular}{ccccccc}
\hline \multicolumn{7}{c}{ Pemerintah Kabupaten Cilacap } \\
\hline \multirow{2}{*}{ Tahun } & \multicolumn{2}{c}{ Pendapatan (dalam ribuah rupiah) } & \multicolumn{2}{c}{ Belanja (dalam ribuah rupiah) } \\
\hline & Anggaran & Realisasi & $\%$ & Anggaran & Realisasi & $\%$ \\
\hline 2014 & 2.286 .449 .415 & 2.367 .534 .100 & 103 & 2.569 .979 .136 & 2.205 .741 .809 & 85 \\
\hline 2013 & 2.074 .300 .760 & 2.121 .355 .398 & 102 & 2.289 .524 .271 & 2.047 .162 .545 & 89 \\
\hline 2012 & 1.730 .602 .349 & 1.792 .439 .254 & 103 & 1.952 .975 .779 & 1.792 .586 .828 & 91 \\
\hline 2011 & 1.610 .106 .238 & 1.639 .234 .442 & 101 & 1.751 .202 .584 & 1.550 .277 .519 & 88 \\
\hline 2010 & 1.315 .167 .381 & 1.334 .620 .370 & 101 & 1.433 .670 .672 & 1.299 .429 .295 & 90 \\
\hline
\end{tabular}

Upaya penghematan belanja yang dilakukan SKPD merupakan bentuk dari praktek efisiensi walaupun jumlahnya tidak signifikan jika dibandingkan dengan besarnya anggaran yang tidak terserap yang menunjukkan rendahnya kualitas perencanaan. Pelampauan target anggaran pendapatan merupakan efek dari sikap kehatihatian pelaksana anggaran dengan menetapkan target anggaran yang moderat dikarenakan adanya berbagai ketidakpastian seperti adanya perubahan regulasi, perubahan kondisi perekonomian masyarakat yang akan menghambat pencapaian target anggaran. Insentif/bonus dari pemerintah pusat terhadap SKPD yang diberikan ketika target anggaran dapat dipenuhi 100\% memberikan motivasi bagi SKPD untuk merealisasikan target pendapatan sebesar 100\% karena jika realisasi pendapatan tidak mencapai 100\% maka SKPD tidak mendapatkan insentif/ bonus dari pemerintah pusat.

Fenomena ketidaktepatan pelaksanaan anggaran dengan adanya sisa lebih perhitungan anggaran (SILPA) selalu terjadi setiap tahun di Kabupaten Cilacap dan hampir terjadi di sebagian besar daerah di Indonesia. Berdasarkan latar belakang di atas maka peneliti bermaksud untuk melakukan analisis untuk memperoleh bukti empiris mengenai faktor-faktor yang mempengaruhi ketepatan anggaran dengan judul penelitian yaitu tekanan eksternal, komitmen organisasi, ketidakpastian lingkungan serta kualitas anggaran terhadap ketepatan pelaksanaan anggaran pada Pemerintah Kabupaten Cilacap.

Tekanan eksternal adalah variabel yang mempengaruhi ketepatan anggaran dalam penelitian ini. Menurut Nay (2011), tekanan eksternal berbentuk peraturan legal, budaya birokrasi dan klaim atau tuntutan dari pemangku kepentingan. Tekanan eksternal terhadap anggaran dalam beberapa penelitian terbukti mempengaruhi kinerja anggaran seperti penelitian yang telah dilakukan oleh Triana, dkk (2012), Aprilia dan Hidayani (2012), Bangun, dkk (2012) serta Salikhah (2013). Ketidakpastian lingkungan selalu bergerak dinamis menuntut organisasi untuk bekerja lebih baik. Ketidakpastian lingkungan yang tinggi didefinisikan sebagai rasa ketidakmampuan individu untuk memprediksi sesuatu yang terjadi di lingkungannya secara akurat (Gregson, 1994). Ketidakpastian lingkungan dalam penelitian terdahulu terbukti berpengaruh terhadap kinerja anggaran, beberapa penelitian tersebut dilakukan oleh Minanda (2009), Sujana (2010) dan Kusuma (2013). Komitmen organisasi merupakan variabel yang sangat mempengaruhi kinerja pegawai untuk mencapai ketepatan anggaran, karena komitmen organisasi yang kuat akan menyebabkan individu berusaha keras mencapai tujuan organisasi (Mowday et al., 1979). Beberapa penelitian telah membuktikan bahwa komitmen organisasi berpengaruh terhadap kinerja anggaran antara lain, penelitian yang dilakukan oleh Azmi (2010), Aprilia dan 
Faktor Yang Mempengaruhi Ketepatan Anggaran...

Hidayani (2012), Salikhah (2013), Kusuma (2013) dan Rustini (2015). Kualitas anggaran terkait dengan kualitas dokumen anggaran yang telah disusun oleh organisasi sektor publik yang digunakan sebagai alat perencanaan dilaksanakannya kegiatan. Kualitas anggaran terbukti berpengaruh terhadap kinerja anggaran seperti penelitian yang dilakukan oleh Seftianova dan Adam (2009), Sugiharto (2013) dan Suluh (2014).

Penelitian-penelitian diatas mencoba menguji pengaruh variabel tekanan eksternal, ketidakpastian lingkungan, komitmen organisasi, dan kualitas anggaran terhadap kinerja anggaran. Sedangkan pada penelitian ini, peneliti mencoba menguji variabel variabel independen tersebut dengan variabel dependen ketepatan anggaran. Hal ini karena fenomena munculnya SILPA selalu terjadi setiap tahun hampir di seluruh organisasi sektor publik yang menunjukkan ketidaktepatan pelaksanaan anggaran. Berdasarkan uraian diatas maka peneliti termotivasi untuk meneliti lebih lanjut tentang pengaruh tekanan eksternal, ketidakpastian lingkungan, komitmen organisasi dan kualitas anggaran terhadap ketepatan anggaran.

Penganggaran sektor publik, terkait dengan proses penentuan jumlah alokasi dana untuk tiap-tiap program dan aktivitas dalam satuan moneter. Proses penganggaran organisasi sektor publik dimulai ketika perumusan strategi dan perencanaan strategi telah selesai dilakukan (Mardiasmo, 2009). Anggaran daerah dikenal dengan sebutan anggaran pendapatan dan belanja daerah (APBD) adalah rencana keuangan pemerintah daerah dalam rangka melaksanakan kewenangannya selama satu tahun anggaran. Fokus pengukuran kinerja berbasis anggaran sebenarnya untuk mengetahui kinerja keuangan daerah, yaitu sejauh mana efektifitas dan efisiensi pengelolaan keuangan daerah (Mahsun, 2006).

Pengannggaran pada Pemerintah Daerah Kabupaten Cilacap dimulai dari rencana pembangunan jangka panjang yaitu 20 (dua puluh) tahunan (RPJP) di legalkan melalui Perda Nomor 23 Tahun 2008, kemudian di jabarkan menjadi rencana pembangunan jangka menengah daerah 5 (lima) tahunan (RPJMD) yang dilegalkan melalui Perda Nomor 5 Tahun 2013. Pelaksanaan penganggaran tahunan sebagai penjabaran dari RPJMD berbentuk rencana kerja perangkat daerah (RKPD) yang pada tahun 2015 dilegalkan melalui Perda Nomor 53 Tahun 2015. Penganggaran dan pelaksanaan anggaran di Kabupaten Cilacap di evaluasi setiap 3 (tiga) bulan sebagai bentuk dari pengendalian anggaran agar supaya anggaran dapat berjalan ekonomis, efektif dan efisien dan mencapai sasaran.

\section{PERUMUSAN HIPOTESIS}

\section{Pengaruh Tekanan Eksternal Terhadap Ketepatan Anggaran Pendapatan dan Belanja Daerah}

Frumkin dan Galaskiewicz (2004) menyatakan bahwa tekanan eksternal dapat mempengaruhi tingkat kemampuan pemerintahan menjadi lebih rendah, terutama yang terkait dengan penerapan suatu kebijakan maupun prosedur. Adanya tekanan eksternal dapat berakibat pada praktik-praktik SKPD yang hanya bersifat formalitas untuk memperoleh legitimasi. Organisasi sektor publik didirikan sebagai pelayan masyarakat, legitimasi diperoleh melalui akuntabilitas vertikal yaitu pengesahan oleh negara dan akuntabilitas secara horizontal yaitu melalui pengakuan dari masyarakat.

Goal setting theory berasumsi bahwa terdapat hubungan langsung antara tujuan yang spesifik dan terukur dengan kinerja. Temuan utama dari goal setting theory adalah bahwa individu yang diberi tujuan yang spesifik dan sulit tapi dapat dicapai akan memiliki kinerja yang lebih baik dibandingkan orang-orang yang menerima tujuan yang mudah dan kurang spesifik atau tidak ada tujuan sama sekali. Dalam goal setting theory terdapat hubungan yang berbanding lurus antara tujuan yang spesifik dan sulit dengan kinerja. Menurut Nay (2011) 
tekanan eksternal dapat dirasakan melalui banyaknya peraturan legal, budaya birokrasi organisasi, dan adanya klaim atau tuntutan langsung dari pemangku kepentingan. Konsep NPM (New Public Management) menimbulkan beberapa konsekuensi bagi pemerintah, di antaranya adalah tuntutan untuk melakukan efisiensi, pemangkasan biaya (cost cutting), dan kompetisi tender (Mardiasmo, 2002). Tuntutan lain berasal dari United Nation Development Program (UNDP) yaitu pelaksanaan Good Governance untuk melaksanakan penggunaan sumberdaya publik secara ekonomis, efektif, efisien yang kemudian di aplikasikan dalam UU Nomor 25 Tahun 2004 tentang azas dan tujuan pembangunan nasional yang menyebutkan bahwa sistem perencanaan pembangunan nasional bertujuan untuk menjamin tercapainya penggunaan sumberdaya secara efisien, efektif, berkeadilan dan berkelanjutan. Tuntutan dari Pemerintah pusat yaitu Perpres Nomor 39 Tahun 2012 tentang pemberian penghargaan dan pengenaan sanksi atas pelaksanaan anggaran belanja kementerian/lembaga.

Penelitian terdahulu dilakukan oleh Triana, dkk. (2012), Aprilia dan Hidayani (2012), Bangun, dkk. (2012) menemukan bahwa tekanan anggaran dari pihak eksternal berpengaruh positif terhadap budgetary slack, sehingga dapat disimpulkan bahwa tekanan terhadap anggaran berpengaruh negatif terhadap ketepatan anggaran karena ketepatan anggaran dalam penelitian ini diproksikan dengan budgetary slack yang kecil.. Besarnya tekanan terhadap anggaran dari pihak vertikal dan horizontal terhadap pelaksanaan anggaran yaitu penggunaan sumberdaya publik berdasarkan prinsip ekonomis, efektifitas dan efisien dengan disertai sanksi dan penghargaan maka mendorong/memotivasi organisasi sektor publik yaitu Pemerintah Daerah Kabupaten Cilacap untuk memberikan citra yang baik dimata pemangku kepentingan sehingga berakibat pada ketidaktepatan anggaran. Berdasarkan uraian di atas, disusun hipotesis dalam konteks pemerintah daerah, sebagai berikut:

\section{$\mathrm{H}_{1}$ :Tekanan eksternal berpengaruh negatif pada ketepatan anggaran.}

\section{Pengaruh Ketidakpastian Lingkungan pada Ketepatan Anggaran Pendapatan dan Belanja Daerah}

Dalam ketidakpastian lingkungan yang rendah (lingkungan dalam keadaan relatif stabil), individu dapat memprediksi keadaan sehingga langkah-langkah yang akan diambil dapat direncanakan dengan lebih akurat (Duncan, 1972). Apabila individu menghadapi kondisi lingkungan yang tidak pasti, akan membuat realisasi anggaran (anggaran aktual) tidak sesuai dengan anggaran yang telah ditetapkan sebelumnya, sehingga akan memperkecil pencapaian sasaran yaitu ketepatan anggaran. Menurut Ridha dan Basuki (2012) ketidakpastian lingkungan adalah kondisi dimana SKPD melakukan penyesuaian yang dapat disebabkan adanya pengaruh dari luar SKPD, seperti sering terjadinya perubahan peraturan, tidak match-nya antara peraturan yang satu dengan yang lain, terjadinya mutasi staf SKPD yang cepat, dan lain sebagainya. Variabel ketidakpastian lingkungan merupakan variabel kontekstual yang penting karena kondisi tersebut akan membuat kegiatan perencanaan dan kontrol menjadi lebih sulit (Chenhall dan Morris,1986).

Berdasarkan penelitian yang dilakukan oleh Kusuma (2013) ditemukan bahwa ketidakpastian lingkungan berpengaruh negatif terhadap ketepatan anggaran Provinsi Bali. Penelitian yang dilakukan oleh Sujana (2010) dan Minanda (2009) menemukan bahwa ketidakpastian lingkungan berpengaruh positif terhadap budgetary slack yang bermakna bahwa ketidakpastian lingkungan berpengaruh negatif pada ketepatan anggaran.

Ketidakpastian lingkungan membuat organisasi memilih untuk bersikap konservatif dan meniru praktik terbaik yang telah dilaksanakan oleh organisasi yang lain untuk memperoleh legitimasi dari pemangku 
Faktor Yang Mempengaruhi Ketepatan Anggaran...

kepentingan (Di Maggio dan Powell, 1983). Anggaran disusun dan direalisasikan dengan dilandasi sikap kehatihatian. Implikasi dari sikap konservatif organisasi adalah target anggaran menjadi tidak tercapai dengan tepat. Ketidakpastian lingkungan dikarenakan perubahan peraturan dan ketidaksesuaian antar peraturan dan kebijakan otonomi daerah membuat pelaksana anggaran mengalami kesulitan untuk menerjemahkannya ke dalam visi dan misi organisasi sehingga membuat sasaran dan tujuan organisasi menjadi kabur/tidak jelas. Sasaran dan tujuan organisasi yang tidak jelas akan menghasilkan kinerja yang rendah (Kenis, 1979), dalam hal ini berkaitan dengan ketepatan pelaksanaan anggaran. Berdasarkan uraian di atas, maka dapat disusun hipotesis dalam konteks pemerintah daerah sebagai berikut:

\section{$\mathrm{H}_{2}$ :Ketidakpastian lingkungan berpengaruh negatif pada ketepatan anggaran.}

\section{Pengaruh Komitmen Organisasi pada Ketepatan Anggaran Pendapatan dan Belanja Daerah}

Pegawai yang didukung dengan komitmen yang tinggi terhadap organisasi (instansi) Pemerintah Daerah akan bekerja sesuai dengan alur tujuan organisasi karena akan mengorbankan kepentingan pribadinya demi kepentingan organisasi sehingga akan mendorong pegawai untuk mencapai target anggaran sesuai dengan sasaran yang ingin dicapai yaitu kinerja ketepatan anggaran. Menurut Mowday, et al. (1979), komitmen organisasi merupakan keyakinan dan dukungan yang kuat terhadap nilai dan sasaran (goal) yang ingin dicapai organisasi.

Pemerintah Daerah Cilacap menerapkan kebijakan anggaran defisit dimana defisit tersebut akan ditutup oleh anggaran pembiayaan yang salah satu sumbernya adalah SILPA. SILPA diperoleh dari selisih/varian antara anggaran pendapatan dan belanja dengan realisasinya. Selisih/varian anggaran dengan realisasinya dilakukan dengan sengaja oleh Pemerintah Daerah dalam rangka memperoleh dana untuk menutup defisit. Realisasi anggaran merupakan bentuk dari kinerja anggaran. Realisasi anggaran bersifat underestimate untuk belanja dan overestimate untuk pendapatan merupakan bentuk dari slack anggaran.

Penelitian yang dilakukan oleh Kusuma (2013) menemukan bahwa komitmen organisasi berpengaruh positif terhadap ketepatan anggaran Pemerintah Provinsi Bali. Penelitian yang dilakukan oleh Salikhah (2014) menemukan bahwa komitmen organisasi berpengaruh positif pada kinerja anggaran Pemerintah Kota Salatiga. Rustini (2015) menemukan bahwa terdapat pengaruh positif komitmen organisasi pada kinerja pengelola anggaran Pemerintah Kabupaten Tabanan, Aprilina dan Hidayani (2012) menemukan bahwa komitmen organisasi berpengaruh negatif pada kesenjangan anggaran Pemkot Bengkulu dan Azmi (2010) menemukan bahwa komitmen organisasi berpengaruh positif pada kinerja keuangan Pemerintah Aceh.

Dengan komitmen organisasi yang tinggi, maka akan diikuti dengan meningkatnya kinerja ketepatan anggaran pendapatan dan belanja. Bentuk ketepatan anggarannya adalah bahwa selisih underestimate belanja dan overestimate pendapatan yang dihasilkan akan sesuai dengan perencanaan dengan varian anggaran yang rendah. Berdasarkan uraian di atas, disusun hipotesis sebagai berikut:

\section{$\mathrm{H}_{3}$ :Komitmen organisasi berpengaruh positif pada ketepatan anggaran.}

\section{Pengaruh Kualitas Anggaran Terhadap Ketepatan Anggaran Pendapatan dan Belanja}

Anggaran merupakan alat untuk mengendalikan, mengkoordinasikan, memotivasi dan mengevaluasi prestasi manajer (Kennis, 1979). Menurut Kenis (1979), anggaran yang baik memiliki karakteristik yaitu anggaran 
memiliki tingkat kesulitan tujuan, adanya evaluasi anggaran, memiliki umpan balik, memiliki sasaran yang jelas dan terdapat partisipasi di dalam proses penyusunannya. Prestasi manajer dalam hal ini adalah berkaitan dengan ketepatan anggaran. Undang-Undang No. 17 Tahun 2003 tentang Keuangan Negara telah memperkenalkan pendekatan penganggaran berbasis kinerja (performance-based budgeting) dalam penyusunan anggaran pemerintah. Bentuk anggaran berbasis kinerja pada tahap implementasi adalah Rencana Kerja Anggaran (RKA).

RKA berbentuk dokumen anggaran yang disusun melalui berbagai proses teknis yang panjang yang merupakan bentuk dari anggaran berbasis kinerja pemerintah di level pelaksanaan. RKA yang memadai akan memberikan kendali, motivasi, evaluasi terhadap kinerja organisasi. Ketepatan anggaran merupakan salah satu bagian dari kinerja anggaran karena berkaitan dengan penyerapan anggaran yang dibandingkan dengan target anggaran.

Penelitian terdahulu yang dilakukan oleh Sugiharto (2013) menemukan bahwa kualitas anggaran berpengaruh signifikan pada efektifitas organisasi Pemerintah Daerah Jambi. Suluh (2014) menemukan bahwa hanya kejelasan sasaran anggaran sebagai kriteria kualitas anggaran yang berpengaruh positif signifikan pada kinerja pelaksanaan anggaran KPPN wilayah Malang. Sefianova dan Adam (2009) menemukan bahwa kualitas DIPA (dokumen anggaran) berpengaruh positif signifikan pada penyerapan anggaran KPPN wilayah Malang.

Dengan adanya perencanaan yang matang dalam RKA akan meningkatkan kualitas serapan anggaran pendapatan dan anggaran belanja sesuai dengan yang direncanakan sehingga berdampak pada ketepatan anggaran dengan slack anggaran yang proporsional. Berdasarkan uraian yang telah disampaikan dapat disimpulkan bahwa kualitas anggaran memiliki pengaruh positif terhadap ketepatan anggaran.

\section{$\mathrm{H}_{4}$ :Kualitas anggaran berpengaruh positif terhadap ketepatan anggaran.}

\section{METODE}

Penelitian ini dilakukan dengan menggunakan metode survey, yaitu suatu bentuk teknik penelitian di mana informasi dikumpulkan dari sejumlah sampel berupa orang. Informasi/data diperoleh melalui pertanyaanpertanyaan baik dilakukan melalui wawancara maupun memberikan kuesioner. Pertanyaan dapat berbentuk pertanyaan terbuka dengan tidak memberikn pilihan jawaban maupun pertanyan tertutup dengan memberikan alternatif pilihan jawaban kepada responden.

Populasi yang menjadi obyek dalam penelitian ini adalah para pejabat yang menduduki jabatan pada tingkat lower manajemen yaitu sebagai pejabat eselon IV di 67 SKPD dari tingkat Kelurahan, Kecamatan, Lemtekda serta Dinas Instansi pada tahun 2016 yang mempunyai anggaran dan realisasi belanja dan pendapatan. Pengambilan sampel dalam penelitian ini menggunakan metode purposive sampling. Responden penelitian adalah para pejabat eselon IV khususnya yang terlibat langsung dalam perencanaan dan pelaksanaan anggaran yaitu para Kasubbag Keuangan sebagai Pejabat Penatausahaan Keuangan dan Kasubbag Perencanaan. Terdapat 672 pejabat di tingkat lower manajemen di 67 SKPD Kabupaten Cilacap, namun hanya 95 pejabat yang dapat dijadikan sampel sesuai dengan kriteria dalam penelitian ini. Kuesioner diberikan terhadap 95 responden, dari total 95 kuesioner yang diberikan terdapat 93 kuesioner yang direspon dan dikembalikan dan dari 93 kuesioner yang dikembalikan terdapat 92 kuesioner yang lengkap dan memenuhi syarat untuk sebagai data penelitian. 
Faktor Yang Mempengaruhi Ketepatan Anggaran...

\section{Tekanan Eksternal (TE)}

Menurut Di Maggio dan Powell (1983), tekanan eksternal adalah tekanan formal dan informal yang diberikan pada organisasi oleh organisasi lain dimana organisasi tergantung dengan harapan budaya masyarakat di mana organisasi menjalankan fungsinya. Indikator dan instrumen tekanan eksternal berdasarkan pada penelitian Di Maggio dan Powell, (1983) yang terdiri dari 6 indikator dan diukur dengan menggunakan skala likert lima point yaitu 1 hingga 5. Jawaban responden terhadap tekanan eksternal berkisar antara 5 sampai dengan 20 dengan skor rata-rata 12,86 dan standar deviasinya sebesar 3,41. Tekanan eksternal yang dialami Pemerintah Daerah Kabupaten Cilacap tergolong rendah, karena memiliki skor rata-rata sebesar 13,86 lebih kecil dari nilai median sebesar 14.

\section{Ketidakpastian Lingkungan (KL)}

Duncan (1972) mendefinisikan ketidakpastian lingkungan sebagai keterbatasan individu dalam menilai probabilitas seberapa besar keputusan yang telah dibuat akan gagal atau berhasil yang disebabkan karena kesulitan untuk mempredksi kemungkinan kemungkinan yang akan terjadi. Indikator dan instrumen ketidakpastian lingkungan diadopsi dari Duncan (1972) yang terdiri dari 9 indikator dan diukur dengan menggunakan skala likert lima point yaitu 1 hingga 5. Jawaban responden terhadap ketidakpastian lingkungan berkisar antara 10 sampai dengan 39 dengan rata-rata skor 21,04 dan standar deviasinya sebesar 6,03. Pemerintah Daerah Kabupaten Cilacap mengalami ketidakpastian lingkungan yang tinggi, karena memiliki skor rata-rata sebesar 21,03 besar dari nilai median sebesar 20.

\section{Komitmen Organisasi (KO)}

Aranya dan Ferris (1984) mendefinisikan komitmen organisasi adalah perjanjian atau keterikatan untuk melakukan sesuatu yang terbaik dalam suatu organisasi atau kelompok tertentu. Indikator dan instrumen komitmen organisasi berdasarkan Aranya dan Ferris (1984) yang terdiri dari 5 indikator dan diukur dengan menggunakan skala likert lima point yaitu 1 hingga 5. Jawaban responden terhadap komitmen organisasi berkisar antara 9 sampai dengan 20 dengan skor rata-rata 16,15 dan standar deviasinya sebesar 2,35. Komitmen organisasi pada Pemerintah Daerah Kabupaten Cilacap tergolong tinggi, karena memiliki skor ratarata sebesar 16,15 lebih besar dari nilai median sebesar 16.

\section{Kualitas Anggaran (KU)}

Kualitas anggaran dalam penelitian ini berhubungan dengan kualitas hasil kerja dari penyusunan anggaran yang dikerjakan oleh pegawai/karyawan dalam rangka menghasilkan suatu produk berupa Rencana Kerja dan Anggaran (Putri, 2012). Indikator dan instrumen kualitas anggaran diadopsi dari penelitian Putri (2012) yang terdiri dari 9 indikator dan diukur dengan menggunakan skala likert lima point yaitu 1 hingga 5. Jawaban responden terhadap kualitas anggaran berkisar antara 24 sampai dengan 45 dengan skor rata-rata 36,64 dan standar deviasinya sebesar 3,54. Kualitas anggaran yang disusun Pemerintah Daerah Kabupaten Cilacap tergolong tinggi, karena memiliki skor rata-rata sebesar 36,64 lebih besar dari nilai median sebesar 36. 


\section{Ketepatan Anggaran (KA)}

Ketepatan anggaran pendapatan dan belanja daerah didefinisikan sebagai slack anggaran yang kecil. Slack anggaran sendiri didefinisikan sebagai perbedaan jumlah anggaran yang disusun oleh pejabat yang berwenang merencanakan anggaran dengan estimasi terbaik yang sebenarnya dapat dicapai (Dunk, 1993). Indikator dan instrumen ketepatan anggaran dalam penelitian ini di adopsi dari penelitian yang dilakukan oleh Dunk (1993) yang terdiri dari 6 indikator dan diukur dengan menggunakan skala likert 5 point yaitu 1 hingga 5. Jawaban responden terhadap ketepatan anggaran berkisar antara 8 sampai dengan 22 dengan rata-rata skor sebesar 14,32 dan standar deviasinya sebesar 3,12. Ketepatan anggaran Pemerintah Daerah Kabupaten Cilacap tergolong rendah, karena memiliki skor rata-rata sebesar 14,32 lebih rendah dari nilai median sebesar 15.

\section{Model Penelitian}

Untuk menguji hipotesis dalam penelitian ini digunakan uji persamaan struktural dengan PLS. Model penelitian dalam PLS berbentuk diagram jalur yang menunjukkan hubungan antar konstruk dengan indikator konstruk dan hubungan antar konstruk. Model konstruk dalam penelitian ini adalah konstruk reflektif unidimensional. Gambar 3.1 adalah gambar persamaan model pengukuran.

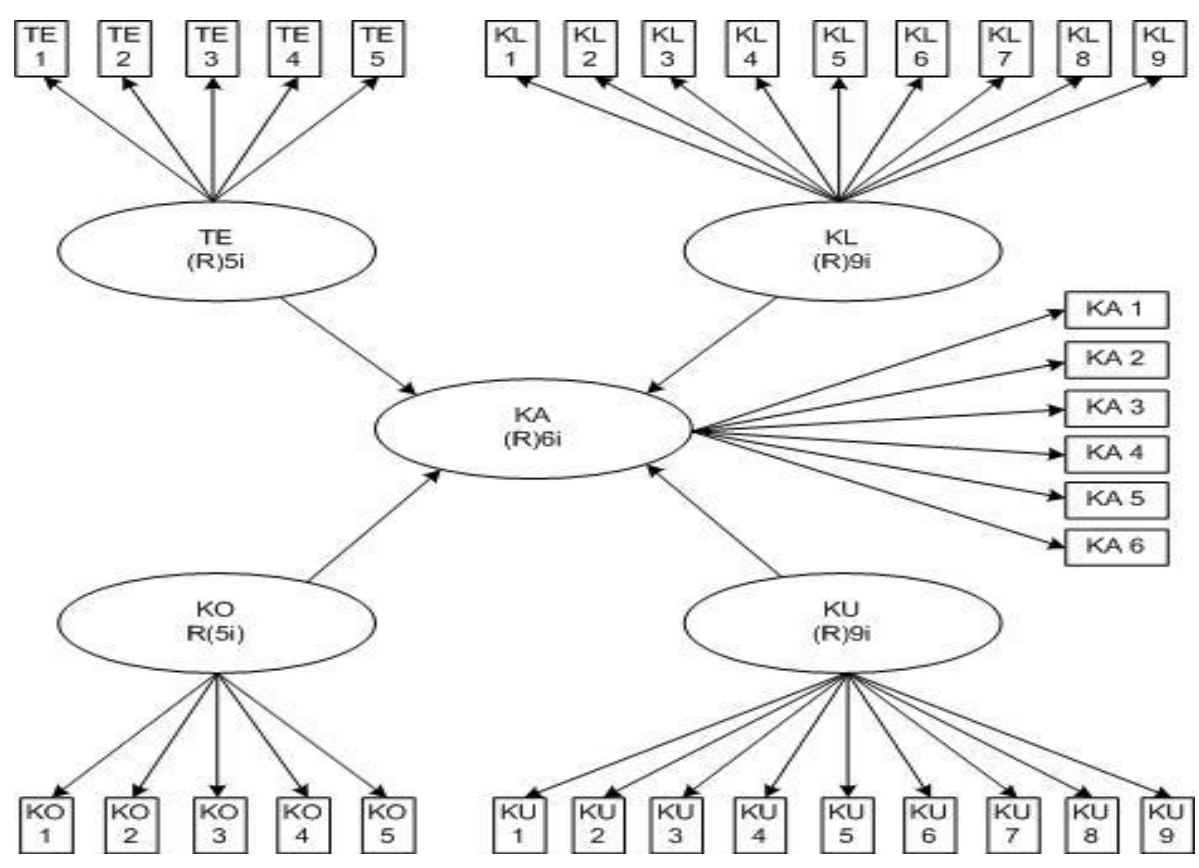

Gambar 3.1 Model penelitian

\section{Hasil}

Pengujian model pengukuran terdiri dari uji validitas dengan mengukur loading factor indikator minimal 0,60 dan nilai AVE minimal 5,50 untuk validitas konvergen (Ghozali, 2014) dan membandingkan nilai akar AVE setiap konstruk harus lebih besar jika dibandingkan dengan nilai korelasi antar konstruk untuk validitas diskriminan (Ghozali, 2014). Sedangkan untuk menguji reliabilitas digunakan nilai composite reliability dengan nilai minimal 0,60 (Ghozali, 2014). Semua konstruk telah memenuhi syarat pengujian model pengukuran. Berikut adalah tabel hasil evaluasi model pengukuran yang berasal dari output WarpPLS 0.4. 
Faktor Yang Mempengaruhi Ketepatan Anggaran...

Tabel 2. Evaluasi Model Pengukuran Validitas Konvergen

\begin{tabular}{|c|c|c|c|c|c|}
\hline & 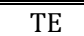 & $\overline{\mathrm{KKL}}$ & 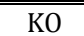 & 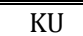 & 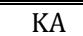 \\
\hline TE1 & 0,806 & & & & \\
\hline TE3 & 0,861 & & & & \\
\hline TE4 & 0,849 & & & & \\
\hline TE5 & 0,874 & & & & \\
\hline KL1 & & 0,754 & & & \\
\hline KL2 & & 0,840 & & & \\
\hline KL3 & & 0,795 & & & \\
\hline KL4 & & 0,727 & & & \\
\hline KL5 & & 0,824 & & & \\
\hline KL6 & & 0,811 & & & \\
\hline KL7 & & 0,750 & & & \\
\hline KL8 & & 0,761 & & & \\
\hline KL9 & & 0,717 & & & \\
\hline K01 & & & 0,854 & & \\
\hline KO2 & & & 0,712 & & \\
\hline K03 & & & 0,785 & & \\
\hline K05 & & & 0,791 & & \\
\hline KU1 & & & & 0,671 & \\
\hline KU2 & & & & 0,685 & \\
\hline KU3 & & & & 0,671 & \\
\hline KU4 & & & & 0,797 & \\
\hline KU5 & & & & 0,711 & \\
\hline KU6 & & & & 0,649 & \\
\hline KU7 & & & & 0,783 & \\
\hline KU8 & & & & 0,711 & \\
\hline KU9 & & & & 0,731 & \\
\hline KA2 & & & & & 0,624 \\
\hline KA3 & & & & & 0,682 \\
\hline KA4 & & & & & 0,879 \\
\hline KA5 & & & & & 0,767 \\
\hline
\end{tabular}

Tabel 3. Hasil Evaluasi Model Pengukuran Validitas Konvergen

\begin{tabular}{ccccc}
\hline \hline TE & KL & KO & KU & KA \\
\hline \hline 0,719 & 0,603 & 0,619 & 0,509 & 0,549 \\
\hline \hline
\end{tabular}

Tabel 4. Hasil Evaluasi Model Pengukuran Validitas Diskriminan

\begin{tabular}{cccccc}
\hline \hline & TE & KL & KO & KU & KA \\
\hline TE & 0,848 & 0,459 & $-0,540$ & $-0,485$ & $-0,645$ \\
\hline KL & 0,459 & 0,776 & $-0,464$ & $-0,472$ & $-0,610$ \\
\hline KO & $-0,540$ & $-0,464$ & 0,787 & 0,596 & 0,640 \\
\hline KU & $-0,485$ & $-0,472$ & 0,596 & 0,714 & 0,643 \\
\hline KA & $-0,645$ & $-0,610$ & 0,640 & 0,643 & 0,741 \\
\hline \hline
\end{tabular}


Tabel 5. Hasil Evaluasi Model Pengukuran Reliabilitas

\begin{tabular}{ccccc}
\hline \hline TE & KL & KO & KU & KA \\
\hline \hline 0.911 & 0.932 & 0.866 & 0.903 & 0.857 \\
\hline \hline
\end{tabular}

Tabel 6. Hasil Evaluasi Model Struktural

\begin{tabular}{|c|c|c|}
\hline Kriteria & Rule of Thumbs & Hasil \\
\hline $\begin{array}{l}\text { R-Square atau } \\
\text { Adjusted } \mathrm{R}^{2}\end{array}$ & $\begin{array}{c}\quad \leq 0,70, \leq 0,45, \leq 0,25 \\
\text { (kuat, moderate, lemah) }\end{array}$ & 0,674 \\
\hline $\begin{array}{l}\mathrm{Q}^{2} \text { Predictive } \\
\text { relevance }\end{array}$ & $\begin{array}{c}\mathrm{Q}^{2}>0 \text { memiliki predictive } \\
\text { relevance } \\
\mathrm{Q}^{2}<0 \text { kurang memiliki } \\
\text { predictive relevance }\end{array}$ & 0,687 \\
\hline APC, ARS, AARS & P-Value $\leq 0,05$ & 0,001 \\
\hline AVIF & $\begin{array}{c}\leq 3,3, \text { namun nilai } \leq 5 \\
\text { masih diterima }\end{array}$ & 1,655 \\
\hline AFVIF & $\begin{array}{c}\leq 3,3, \text { namun nilai } \leq 5 \\
\text { masih diterima }\end{array}$ & 2,027 \\
\hline $\begin{array}{l}\text { Goodness } \\
\text { Tenenhaus }\end{array}$ & $\begin{array}{c}\geq 0,10, \geq 0,25, \geq 0,36 \\
\text { (kecil, menengah, besar) }\end{array}$ & 0,642 \\
\hline SPR & Idealnya = 1 & 1 \\
\hline RSCR & Idealnya = 1 & 1 \\
\hline SSR & Harus $\geq 0,7$ & 1 \\
\hline NLBCDR & Harus $\geq 0,7$ & 1 \\
\hline Signifikansi & $\begin{array}{c}\text { P-value } 0,05 \text { (significance } \\
\text { level }=5 \% \text { ) }\end{array}$ & $<0,05$ \\
\hline
\end{tabular}

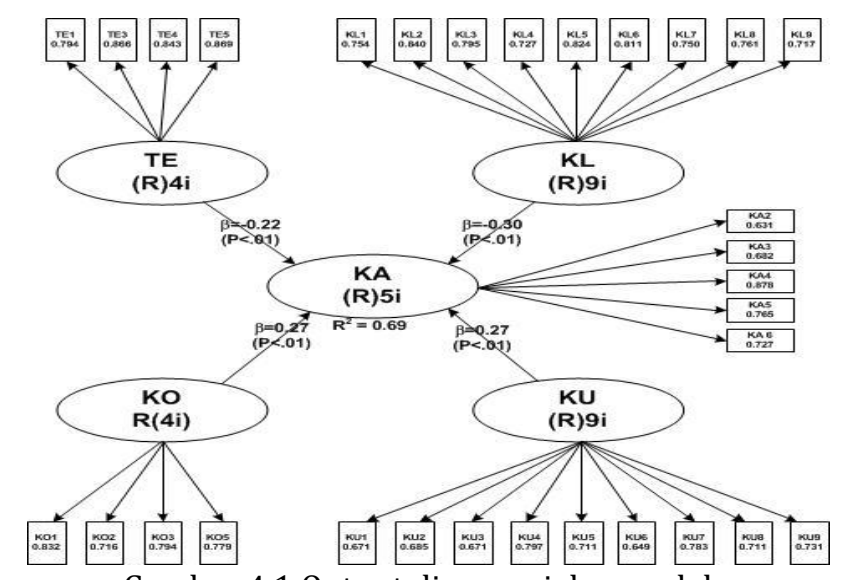

Gambar 4.1 Output diagram jalur model 
Faktor Yang Mempengaruhi Ketepatan Anggaran...

\section{Pengujian Model Struktural}

Pengujian model struktural terdiri dari berbagai kriteria antara lain adalah dengan melihat nilai Adjusted $\mathrm{R}^{2}$, effect sizeQ-Square predictive relevance, average path coefficient (APC), average R-squared (ARS), average adjusted R-Squared (AARS), average block variance inflation factor (AVIF), average full collinearity VIF (AFVIF), simpson paradox ratio (SPR), R-Squared contribution ratio (RSCR), statistical suppression ratio (SSR), nonlinear bivariate causality direction ratio (NLBCDR), goodness of fitindex (GoF). Pengujian yang terakhir adalah untuk menguji hipotesis dengan melihat nilai koefisien jalur dan signifikansinya. Model struktural dalam penelitian ini telah memenuhi syarat kriteria evaluasi model struktural. Tabel 3.5 adalah tabel hasil pengujian model struktural yang berasal dari output WarpPLS 0.4.

\section{Uji Hipotesis}

Uji hipotesis dilakukan untuk mendapatkan jawaban atas dugaan adanya hubungan/korelasi antara konstruk dependen dan independen dalam suatu penelitian. Hasil korelasi antar konstruk diukur dengan melihat koefisien jalur dan tingkat signifikansinya kemudian membandingkannya dengan hipotesis penelitian. Interprestasi dan ringkasan hasil pengujian hipotesis disajikan dalam gambar 4.1 dan tabel 4.1.

Berdasarkan tabel 4.1, diperoleh keterangan bahwa variabel tekanan eksternal berpengaruh negatif signifikan terhadap variabel ketepatan anggaran pada Pemerintah Daerah Kabupaten Cilacap, keputusan ini berdasarkan nilai koefisien jalur yaitu $-0,22$ dan nilai P-Value sebesar 0,03. Keputusan yang dapat diambil dalam penelitian ini adalah menerima $\mathrm{H}_{1}$ dan menolak $\mathrm{H}_{0}$. Demikian juga untuk variabel ketidakpastian lingkungan berpengaruh negatif signifikan terhadap variabel ketepatan anggaran pada Pemerintah Daerah Kabupaten Cilacap yang dapat diamati melalui nilai koefisien jalur yaitu -0,30 dan nilai P-Value sebesar 0,01. Keputusan yang dapat diambil dalam penelitian ini adalah menerima $\mathrm{H}_{2}$ dan menolak $\mathrm{H}_{0}$. Hal yang sama untuk variabel komitmen organisasi berpengaruh positif signifikan terhadap variabel ketepatan anggaran pada Pemerintah Daerah Kabupaten Cilacap yang dapat diamati melalui nilai koefisien jalur yaitu sebesar 0,27 dan PValue sebesar 0,01. Keputusan yang dapat diambildalam penelitian ini adalah menerima $\mathrm{H}_{3}$ dan menolak $\mathrm{H}_{0}$. Mirip dengan hasil pengujian diatas, untuk variabel kualitas anggaran berpengaruh positif signifikan terhadap variabel ketepatan anggaran pada Pemerintah Daerah Kabupaten Cilacap yang dapat diamati melalui nilai koefisien jalur yaitu sebesar 0,27 dan P-Value sebesar 0,01. Keputusan yang dapat diambil dalam penelitian ini adalah menerima $\mathrm{H}_{4}$ dan menolak $\mathrm{H}_{0}$.

Tabel 7. Hasil Pengujian Hipotesis

\begin{tabular}{cccc}
\hline Hipotesis & $\begin{array}{c}\text { Nilai Koefisien } \\
\text { Jalur }\end{array}$ & P-Value & Kesimpulan \\
\hline $\mathrm{H}_{1}$ & -0.22 & $<0.05$ & Diterima \\
\hline $\mathrm{H}_{2}$ & -0.30 & $<0.05$ & Diterima \\
\hline $\mathrm{H}_{3}$ & 0.27 & $<0.05$ & Diterima \\
\hline $\mathrm{H}_{4}$ & 0.27 & $<0.05$ & Diterima \\
\hline
\end{tabular}

Sumber: Data primer diolah 


\section{Pembahasan}

Adanya tekanan eksternal dari para pemangku kepentingan perihal efisiensi dan efektivitas penggunaan anggaran adalah merupakan tujuan sulit dan spesifik yang memerlukan upaya yang keras untuk mewujudkannya. Ketika tujuan organiasi sangat sulit dicapai, manajer sektor publik merasa tidak berhasil dari usaha mereka. Akibatnya, pekerja menjadi frustasi terhadap tujuan organisasi itu. Tujuan yang sangat ketat dan tidak dapat dicapai, mengarahkan pada perasaan gagal, frustrasi, tingkat aspirasi yang rendah (Kenis, 1979). Perasaan frustasi memotivasi seorang manajer sektor publik untuk berperilaku disfungsional dalam pengelolaan anggaran demi membela kepentingan dirinya sendiri. Ketika para manajer sektor publik merencanakan dan menyusun anggaran maka mereka akan menetapkan target/tujuan anggaran yang mudah sehingga dia tidak perlu bekerja keras untuk mencapai tujuan tersebut bahkan untuk melampauainya sehingga akan mengurangi tingkat ketepatan anggaran pada tahap pelaksanaannya.

Manajer sektor publik merasa adanya kesulitan tujuan organisasi dikarenakan adanya ketidakpastian lingkungan yang menuntut organisasi untuk menyesuaikan diri dengan perubahan lingkungan. Tujuan yang sangat ketat dan tidak dapat dicapai, mengarahkan pada perasaan gagal, frustrasi, tingkat aspirasi yang rendah (Kenis, 1979). Apabila tujuan organisasi sulit untuk dicapai maka akan memberikan dorongan pada seseorang untuk bekerja lebih baik, namun tujuan yang terlalu sulit dapat menyebabkan seseorang mengalami frustasi dan mengambil berbagai tindakan disfungsional yaitu dalam pengelolaan anggaran dengan tujuan mempermudah pencapaian target anggaran yang ditetapkan melalui penganggaran yang longgar (slack budgeting) sehingga akan memperkecil tingkat ketepatan anggaran dalam tahap pelaksanaannya.

Teori penetapan tujuan menyatakan bahwa tujuan yang sulit dan spesifik akan menghasilkan kinerja yang lebih baik daripada tujuan yang mudah dan tidak spesifik bahkan tidak ada tujuan sama sekali (Locke dan Latham, 1968). Menurut Wegge, et al. (2009), jika tidak ada komitmen maka penetapan tujuan dari seorang supervisor atau yang lain akan memiliki dampak yang kecil atau tidak berdampak sama sekali terhadap kinerja. Komitmen organisasi dapat dikatakan komitmen seluruh pegawai untuk mencapai tujuan organisasi. Tujuan organisasi yang sulit dan spesifik, dalam hal ini adalah ketepatan anggaran merupakan tujuan organisasi untuk menyelesaikan program dan kegiatan dengan sisa dana yang tidak berlebihan.

Teori penetapan tujuan menyatakan bahwa tujuan yang sulit dan spesifik akan menghasilkan kinerja yang lebih baik daripada tujuan yang mudah dan tidak spesifik bahkan tidak ada tujuan sama sekali. Anggaran merupakan bentuk dari penetapan tujuan, anggaran juga merupakan alat untuk mengendalikan, mengkoordinasikan, memotivasi dan mengevaluasi prestasi manajer (Kennis, 1979). Kenis (1979) menyimpulkan bahwa kualitas anggaran (berdasarkan 5 karakteristik anggaran: partisipasi, kejelasan sasaran, evaluasi, umpan balik dan tingkat kesulitan) berpengaruh signifikan terhadap sikap/perilaku manajer terhadap anggaran (attitudes toward budgets) serta berpengaruh signifikan terhadap kinerja anggaran (budget performance) dimana salah bentuk kinerja anggaran adalah ketepatan anggaran.

\section{Simpulan}

Penelitian ini membuktikan secara empiris bahwa tekanan eksternal berpengaruh negatif terhadap ketepatan anggaran. Hal ini berarti semakin tinggi frekuensi tekanan dari pihak luar berupa peraturan- peraturan, pemberitaan serta tuntutan dari pemangku kepentingan pengguna sarana dan prasarana pemerintah perihal 
Faktor Yang Mempengaruhi Ketepatan Anggaran...

efektivitas dan efisiensi anggaran maka akan semakin memperkecil pencapaian ketepatan anggaran dan sebaliknya.

Penelitian ini membuktikan secara empiris bahwa ketidakpastian lingkungan berpengaruh negatif terhadap ketepatan anggaran. Hal ini berarti semakin tinggi ketidakpastian lingkungan berupa tingginya frekuensi pergantian peraturan, adanya mutasi pegawai yang cepat serta banyaknya peraturan yang tidak sinkron satu sama lain sehingga sulit dilaksanakan mengenai anggaran maka akan semakin memperkecil pencapaian ketepatan anggaran dan sebaliknya.

Penelitian ini membuktikan secara empiris bahwa komitmen organisasi berpengaruh positif terhadap ketepatan anggaran. Hal ini berarti semakin tinggi komitmen yang dimiliki pegawai organisasi sektor publik berupa kedekatan emosional antara pegawai dengan organisasi, perasaan bangga menjadi anggota organisasi serta pemahaman terhadap tujuan organisasi tempat seseorang bekerja maka akan semakin memperbesar pencapaian ketepatan anggaran dan sebaliknya.

Penelitian ini membuktikan secara empiris bahwa kualitas anggaran berpengaruh positif terhadap ketepatan anggaran. Hal ini berarti, semakin tinggi kualitas penyusunan anggaran dimana anggaran yang disusun telah memenuhi berbagai kriteria dan karakteristik tujuan anggaran maka akan memperbesar pencapaian ketepatan anggaran dan sebaliknya.

\section{Saran}

Pemerintah daerah perlu menimimalisir tekanan eksternal khususnya dari para stakeholder melalui penerapan transparansi pengelolaan anggaran, sehingga tidak terjadi asimetri informasi dan menciptakan persepsi yang berbeda antara pemerintah daerah dengan para stakeholder yang memicu tekanan eksternal yang berlebihan. Pemerintah daerah beserta jajaran pendukungnya perlu menyikapi adanya ketidakpastian lingkungan dengan meningkatkan kemampuan dalam memprediksi dan mengantisipasi berbagai perubahan lingkungan yang akan terjadi dimasa depan melalui pendidikan dan pelatihan berkelanjutan terhadap pegawai sehingga para pegawai menciptakan perencanaan anggaran dengan kualitas yang mampu menghadapi ketidakpastian lingkungan.

Selain itu pemerintah daerah juga perlu meningkatkan komitmen pegawai pada tujuan organisasi sehingga akan mengurangi perilaku disfungsional pegawai dalam menyusun dan melaksanakan anggaran melalui pemberian penghargaan terhadap pegawai yang sesuai dengan beban kerja dan prestasinya, sehingga para pegawai merasa kerja kerasnya dihargai dan tetap loyal kepada organisasi. Demikian juga, pemerintah daerah perlu melakukan pengawasan yang ketat terhadap penyusunan anggaran sehingga kualitas anggaran yang dihasilkan menjadi semakin baik melaui e-budgeting, penyusunan standar indeks satuan harga yang tepat dan kajian oleh badan independen terhadap potensi pendapatan dan pengeluaran daerah.

\section{Keterbatasan Penelitian}

Penggunaan survey kuesioner dengan individu sebagai unit analisisnya, lebih cenderung merespon pertanyaan dengan jawaban yang bias karena isu pelaksanaan anggaran yang selama ini terjadi menunjukkan kelemahan manajemen sektor pemerintah. Keterbatasan selanjutnya adalah pada latar belakang pendidikan responden yang mayoritas berpendidikan non-ekonomi sehingga data yang didapatkan tidak berdasarkan fakta sebenarnya karena pengetahuan tentang anggaran pada responden kurang memadai. Oleh karenanya untuk penelitian 
selanjutnya, latar belakang pendidikan sangat mungkin untuk dijadikan variabel kontrol dalam model penelitiannya.

\section{DAFTAR PUSTAKA}

Allen, NJ. dan Meyer, JP. 1990. Measurement and anticedent of affective, continuance and normatif commitment. Journal of occupacional psycology, Vol. 63, No.1.

Armstrong, M. dan Baron, A. 1998. Performance Management: The New Realities,Institute of Personnel and Development, New York.

Aprilina, N dan Hidayani, S. 2012.The Effect Of Budgetary Participation, Asymmetry Information, Budget Emphasis And Comitment Organization To Budgetary Slack At SKPD Governmental Of Bengkulu City. PROCEEDINGThe 13th Malaysia Indonesia Conference on Economics, Management andAccounting (MIICEMA).

Aranya, N., dan Ferris, K. A. 1984. “Reexamination of Accountants Organizational Professional Conflict.” The Accounting Review, Vol. LIX. No.3

Azmi, G. 2010. Pengaruh Kejelasan Anggaran, Kualitas Sumberdaya Manusia dan Komitmen Organisasi Terhadap Kinerja Pengelolaan Keuangan Daerah Di lingkungan Pemerintah Aceh. Jurnal Universitas Syiah Kuala.

Bangun, Nurainun. dkk. 2012. Pengaruh Budget Participation, Information Asymmetry, Budget Emphasis, dan Self Esteem terhadap Budgetary Slack.Jurnal Akuntansi Vol 12, No. 1.

Brown SP, Jones E., Leigh TW. 2005. The attenuating effect of role overload on relationships linking self-efficacy and goal level to work performance. Journal of Applied Psychology.

Chenhall, R.H dan Morris, D. 1986. The Impact of Structure, Environment, and Interdependence on The Perceived Usefulness of Management Accounting Systems. The Accounting Review.Vol. 1, No.1.

Chin, W.W. 1995. Partial least square is to LISREL as principal components analysis is to common factor analysis. Technology Studies, 2.

Chong V.K. dan Chong K.M. 1997. Strategic Choices, Environment Uncertainty and SBU Performance: A Note on the Intervening Role of Management Accounting Systems. Accounting and Bussines Research, Vol. 27. No. 4.

Collins, F. 1978. The Interaction of Budget Characteristics and Personality Variables with Budgetary Response Attitudes. The Accounting Review Vol. III, No.2.

Demanik, AZ. 2011. Pengaruh Budgetary Goal Characteristic dan Keadilan Prosedural Terhadap Kinerja Manajerial (Pada Pejabat Eselon III dan IV Pada Pemerintah Kota Tebing Tinggi). Tesis. Medan: Program Pasca Sarjana Universitas Sumatera Utara.

Dezmiyawati dan Azlina N. 2009. Hubungan strategi, Ketidakpastian Lingkungan dan Kinerja : Informasi Broadscope Sistem Akuntansi Manajemen Sebagai Variabel Intervening . Laporan Penelitian: Lembaga Penelitian Universitas Riau Pekanbaru.

DiMaggio, P. J. dan W. W. Powell. 1983. The Iron Cage Revisited: Institutional Isomorphism and Collective Rationality in Organizational Fields. American Sociological Review.

Duncan, R.B. 1972. Characteristic of Organizational Environments and Perceived Environmental Uncertainty. Administrative Science Quarterly, Vol. 17, No. 3.

Dunk, A. S. 1993. The Effect of Budget Emphasis and Information Asymmetry on the Relation Between Budgetary Participation and Slack. The Accounting Review.

Fadli, M. 2012. Analsis Prosedur dan Varians Anggaran Penjualan Pada CV. Agung Jaya Art Palembang. Jurnal POLTEK PalComTech Palembang.

Frumkin, P. dan J. Galazkiewich.2004. institusional $\quad 41$ sm and public sector organization. Journal of public administration research and theory.

Ghozali, I. 2014. Partial Least Squares, Konsep, Metode dan Aplikasi. Semarang: Badan Penerbit Universitas Diponegoro. 
Govindarajan, V. 1984. Appropriateness of Accounting Data in Performance Evaluation: An Empirical Examination of Environmental Uncertainty as An Intervening Variable. Accounting Organizations and Society.

Govindarajan, V. 1986. Impact of participation In the budgetary process on Managerial attitudes and performance Universalistic and Contingency perspectives. AmosTuck School of Business Administration, Dartmouth College.

Gregson, T., J. Wendell, J. Aono. 1994. Role Ambiguity, Role Conflict, AndPerceived Environmental Uncertainty: Are The Scales Measuring Separate Construct For Accountants. Behavioral Research In Accounting. Vol. 6.

Gul, A.F. dan Chia Y.M. 1994. The Effects of Management Accounting Sistems, Perceived Environmental Uncertainty and Decentralization on Managerial Performance. Accounting organizations and society. Vol. 19, No. 45.

Halim, A.T. dan M. F. Husien. 2000. Sistem Pengendalian Manajemen. Edisi Revisi, Yogyakarta: UPP AMP YKPN.

Hansen dan Mowen, 2006. Managerial Accounting Akuntansi Manajerial. Buku 1 Edisi ketujuh, Jakarta: Salemba Empat.

Hartono, J. M. 2009. Konsep dan Aplikasi PLS (Partial Least Square) Untuk Penelitian Empiris. Edisi I, BPFE, Yogyakarta.

Hess, D. 2007. Social reporting and new goverment regulation: the prospect of corporate accountability trough transparency. Busines ethics quarterly.

Hoque, Z. 2002. A contingency model of the association between strategy, environmental uncertainty and performance measurement: impact on organizational performance. International Business Review.

Izudin, S.S. 2013. Kinerja keuangan daerah dan hubungan dengan Silpa di Kabupaten Bungo.Jurnal Perspektif Pembiayaan dan Pembangunan Daerah Jambi.

Judge T.A. dan Ilies R. 2002.Relationship of personality to performance motivation: A metaanalytic review. Journal of Applied Psychology,Vol.87.

Kartika, A. 2010. Pengaruh Komitmen Organisasi dan Ketidakpastian Lingkungan Dalam Hubungan Antara Partisipasi Anggaran Dengan Senjangan Anggaran. Jurnal Kajian Akuntansi, Vol. 2 No. 1.

Katz, D. dan Kahn, R. L. 1978. The Social Psychology of Organizations. New York: Wiley.

Kenis, I. 1979. Effect on Budgetary Goal Characteristic on Managerial Attitudes and Performance. The Accounting Review, Vol. LIV, No. 4.

Kerlinger, Fred. N. 1973. Foundation of Behaviour Research. Holt. Rinehart and Winston, $2^{\text {nd }}$ edition.

Klein H.J., Wesson M.J., Hollenbeck J.R., Alge B.J. 1999. Goal commitment and the goal setting process: Conceptual clarification and empirical synthesis. Journal of Applied Psychology.

Kren, L., 1993, Budgetary Participation and Managerial Performance The Impact of Information and Environment Volatility. The Accounting Review.

Kurniawan, M.R.N. 2011. Pengaruh Komitmen Organisasi, Budaya Organisasi, dan Kepuasan Kerja Terhadap Kinerja Organisasi Publik. Skripsi: Universitas Diponegoro.

Kusuma, I.G.E.A. Pengaruh Tekanan Eksternal, Ketidakpastian Lingkungan dan Komitmen Organisasi terhadap Ketepatan Anggaran. Tesis. Denpasar: Program Pascasarjana Universitas Udayana.

Latham, G. P. dan Pinder, C. C. 2005. Work motivation theory and research at the dawn of the twenty-first century. Annual Reviews Psychology.

Latham, G.P. dan Locke, E.A. 1991. Self-regulation through goal-setting. Organization BehaviorHuman Decision Process.

Latham, G.P. dan Yukl, G.A. 1975. A review of $\mathrm{r}$ Academy of Management Journal 18.

on the application of goal setting in organizations.

Locke E.A. dan Latham G.P. 2006. New directions in goal setting theory. Current Directions in Psychological Science. 
Locke E.A. dan Latham G.P. 2002. Building a practically useful theory of goal setting and task motivation. American Psychologist.

Locke, E.A. dan Latham, G.P. 1990. A theory of goal setting and task performance. Englewood Cliffs, NJ: Prentice Hall.

Locke, E.A. 1968. Toward A Theory of Task Motivation and Incentives. American Institutes of Research. No.16.

Meyer, J.W. and W.R. Scott (1983) Organizational Environments: Ritual and Rationality.

Mia, L. 1989. The Impact Of Participation In Budgeting And Job Difficulty On Managerial Performance And Work Motivation: A Research Note. Accounting Organizationsand Society, Vol. 14, No. 4.

Mahsun, M. 2006. Pengukuran Kinerja Sektor Publik. Yogyakarta, Indonesia: BPFE UGM.

Mardiasmo. 2009. Akuntansi Sektor Publik. Yogyakarta, Indonesia: Andi.

2002. Otonomi Daerah Sebagai Upaya Memperkokoh Basis Perekonomian Daerah. Jurnal Ekonomi Rakya..

Miliken, F. J. 1987. Three Types of Perceived Uncertainty About Environmental: State, Effect and Response Uncertaint. Academy of Management Review.

Minanda, Y. 2009. Pengaruh Sasaran Anggaran, Komitmen Organisasi dan Ketidakpastian Lingkungan Pada Kesenjangan Anggaran. Tesis. Medan: Program Pasca Sarjana Universitas Sumatra Utara.

Mowday, R., R. Steers, dan L. Porter, 1979. The Measurement of Organizational Commitment. Journal of Vacational Behavior.

Mulyadi. 2001. AkuntansiManajemen Konsep, Manfaat dan Rekayasa. Edisi Ketiga. Jakarta: Salemba Empat.

Nay,O. 2011. Whats Drives Reform In International Organizations Eksternal Pressure In Bearaucratic Enterpreneur in the UN Response in AIDS. An International Journal of Policy, Administration and Institutions, Vol. 24, No. 4.

Nouri H. dan Parker R.J. 1998. The Relationship Between Budget Participation And Job Performance: The Roles Of Budget Adequacy and Organizational Commitment. Accounting, Organizatiom and Society, Vol. 23, No. 5.

Pangestu,A.A. 2014. Pengaruh Kepuasan Kerja Dan Komitmen Organisasional Terhadap Kinerja Pegawai (Studi Pada BNI KCU Undip Semarang). Skripsi: Universitas Diponegoro.

Putri, D. 2012. Pengaruh Kompetensi dan Motivasi Terhadap Kualitas Anggarandengan Regulasi sebagai Variabel Moderasi (Studi Pada Pemerintah Daerah Kota Padang. Tesis: Universitas Andalas

Powell, T.C., Lovallo, D. dan Caringal, C. 2006. Causal ambiguity, management perception, and firm performance. Academy of Management Journal, Vol.31, No. 1.

Republik Indonesia. Peraturan Pemerintah Republik Indonesia No. 108 tahun 2000 Tentang Tata cara Pertanggungjawaban Keuangan Kepala Daerah. Departemen Dalam Negeri Republik Indonesia.

Undang - Undang Republik Indonesia No.17 tahun 2003 Tentang Keuangan Negara. Nasional.

Undang - Undang Republik Indonesia No. 25 tahun 2004 Tentang Azas dan Tujuan Pembangunan

Undang-Undang Republik Indonesia No. 32 tahun 2004 tentang Pemerintahan Daerah. Depertemen Dalam Negeri Republik Indonesia.

. Undang-Undang Republik Indonesia No. 33 tahun 2004 tentang Perimbangan Keuangan antara Pemerintah Pusat dan Daerah. DepertemenDalam Negeri Republik Indonesia.

Peraturan Pemerintah Republik Indonesia No. 58 tahun 2005 Tentang Pengelolaan Keuangan Daerah. Departemen Dalam Negeri Republik Indonesia.

. Peraturan Menteri Keuangan Republik Indnnosia No. 249 tahun 2011 Tentang Pengukuran Kinerja RKA Kementerian dan Lembaga. Kementerian 43 an Republik Indonesia.

Peraturan Presiden Republik Indonesia No. 39 tahun 2012 Tentang Pemberian Penghargaan dan Pengenaan Sanksi Atas Pelaksanaan Anggaran Belanja Kementerian/Lembaga. Sekretariat Kabinet Republik Indonesia. 
Faktor Yang Mempengaruhi Ketepatan Anggaran...

Ridha, M.A. dan Basuki, H. 2012. Pengaruh Tekanan Eksternal, Ketidakpastian Lingkungan dan Komitmen Managemen Terhadap Penerapan Transparansi Pelaporan Keuangan. Simposium Nasional Akuntansi 15 Banjarmasin.

Rustini, N.K.A. 2015. Pengaruh Kompensasi Dan Lingkungan Kerja Pada Komitmen Organisasi dan Implikasinya pada Kinerja Pengelola Anggaran. Tesis: Universitas Udayana.

Sabaruddinsah. 2010.Pengaruh ketidakpastian lingkungan yang dipersepsikan dan strategi kompetitif terhadap hubungan sistem kontrol akuntansi dengan kinerja perusahaan. Jurnal Universitas Negeri Malang.

Salikhah, L. 2014.Analisis Faktor - Faktor yang Berpengaruh Terhadap Kinerja Anggaran Kota Salatiga. Jurnal Universitas Kristen Satya Wacana Salatiga.

Schiff, M. dan A.W. Lewin. 1970. The Impact of People on Budgets. The Accounting Review. Vol. 45.

Seftianova R. dan Adam H. 2013. Pengaruh Kualitas Dipa Dan Akurasi Perencanaan Kas Terhadap Kualitas Penyerapan Anggaran Pada Satker Wilayah Kppn Malang.JRAK Vol. 4 No.1.

Sudarmanto, Gunawan. R. 2005. Analisis Regresi Linier Ganda dengan SPSS. Yogyakarta; Graha Ilmu.

Sugiharto. 2013. Pengaruh Kualitas Anggaran dan Pengendalian Anggaran Terhadap Efektivitas Organisasi di Lingkungan Pemerintahan Kota Jambi. Tesis: Universitas Jambi.

Sugiyono. 2010. Metode Penelitian Bisnis, Bandung: CV. Alfabeta.

Sujana, I. K. 2010. Pengaruh Partisipasi Penganggaran, Penekanan Anggaran, Komitmen Organisasi, Asimetri Informasi, dan Ketidakpastian Lingkungan Terhadap Budgetary Slack Pada Hotel-Hotel Berbintang Di kota Denpasar. E-journal Universitas Udayana. Vol. 5. No. 2.

Suluh A.R.B. 2014. Pengaruh Karakteristik Penganggaran Terhadap Kinerja Pelaksanaan Anggaran Pemerintah Studi Pada Satker KPPN Wilayah Malang. Jurnal Ilmiah Mahasiswa FEB Universitas Brawijaya. Vol. 1 No. 2.

Supriyono. R.A. 2000. Akuntansi Manajemen. Edisi Pertama. Yogyakarta: STIE YKPN.

Triana, Maya dkk.2012. Pengaruh Partisipasi Anggaran, Budget Emphasis dan Locus of Control terhadap Slack Anggaran. e-Journal BINARAKUNTANSI Vol 1 no 1

Tunti, Maria E.D. 2008. Pengaruh Kepuasan Kerja, Komitmen Organisasi, Dan Motivasi Terhadap Kinerja Manajerial Pemerintah Daerah. Tesis: Universitas Gadjah Mada.

Wright, P.M., George, J. M., Farnsworth, S. R., McMahan, G. C. 1993. Productivity and extrarole behavior: The effects of goals. Journal of AppliedPsychology.

Yu, B. 2011. Test of mediating effect of self-regulation between transformational leadership and organizational commitment. Business and Management Review Vol.1, No.6. 